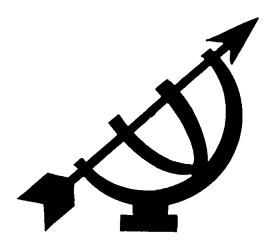

\title{
Switserland en die beginsel van nie- inmenging in die internasionale reg tydens die Anglo-Boereoorlog, 1899-1902
}

\author{
Andries Raath \\ Departement Staatsreg en Regsfilosofie \\ Universiteit van die Vrystaat \\ BLOEMFONTEIN \\ E-pos: raathA.RD@mail.uovs.ac.za
}

\begin{abstract}
Switzerland and the principle of non-intervention in international law during the Anglo-Boer War, 1899-1902

The outbreak of the Anglo-Boer War on 11 October 1899 hit the world like a bomb blast. The news of the war produced strong anti-British sentiments in certain quarters: not only did poets, writers and politicians of international stature, as well as the press, exert strong influence on the public, nations also pressurised their governments to side against Britain. This article investigates the complex position of Switzerland in terms of its official policy of non-intervention in the international world. The following concomitant aspects are also investigated: the pressure exerted on Swiss authorities to express sympathy with the Boer Republics; the growing awareness of the humanitarian implications of Britain's scorched-earth policy of massing together the civil population of the Boer Republics, and the resultant pleas to stop these methods of warfare. The Swiss position of non-intervention in international affairs was severely tested in its efforts to remain legally neutral in the international arena. Switzerland's decision to remain neutral in the war, was finally determined by various factors in the sphere of international law and politics. The developments in Switzerland during the war reflect the transition from positivism towards a stronger humanitarian spirit in international law and politics.
\end{abstract}




\section{Opsomming}

\section{Switserland en die beginsel van nie-inmenging in die internasionale reg tydens die Anglo-Boereoorlog, 1899-1902}

Die uitbreek van die Anglo-Boereoorlog op 11 Oktober 1899 het die wêreld soos 'n skokgolf getref. Nuus van die oorlog het sterk anti-Britse sentimente in sommige oorde tot gevolg gehad: nie alleen het digters, skrywers en politici van internasionale statuur, asook die pers die publiek sterk beïnvloed nie, volkere het ook druk op hul regerings uitgeoefen om teen Brittanje kant te kies. In hierdie artikel word die komplekse posisie van Switserland in terme van sy amptelike beleid van nonintervensie in die internasionale wêreld, ondersoek. Ook die volgende gepaardgaande aspekte word nagegaan: die druk wat op die Switserse owerhede uitgeoefen is om simpatie met die Boererepublieke te toon op grond van die humanitêre implikasies van die Britse verskroeide-aarde-beleid en die samehokking van die burgerlike bevolking van die Boererepublieke, en die gevolglike pleidooie dat hierdie metodes van oorlogvoering gestuit moet word. Die Switserse posisie van non-intervensie in internasionale aangeleenthede is tot die uiterste getoets in sy pogings om regtens neutraal in die internasionale arena te bly. Switserland se besluit om in die oorlog neutraal te bly is in die laaste instansie deur verskillende faktore in die sfeer van die internasionale reg en politiek bepaal. Die ontwikkelinge in Switserland gedurende die oorlog weerspieël die oorgang van positivisme na 'n sterker humanitêre gees in die internasionale reg en politiek.

\section{Inleiding}

Die beginsel van neutraliteit in Switserland se internasionale verhoudinge was aanvanklik die produk van pragmatiese denke oor non-intervensie in die internasionale arena.

- Eerstens moet die Switserse rol in die internasionale regsverkeer tydens die laaste helfte van die 19de eeu beoordeel word teen die agtergrond van Brittanje se dominante rol in die internasionale wêreld (Raath \& Strydom, 1999:149-151). Vanweë Brittanje se leidinggewende rol as internasionale moondheid teen die einde van die 19de eeu, is internasionale verhoudinge grootliks bepaal deur Brittanje se standpunte (Raath \& Strydom, 1999:150).

- Tweedens is Switserland se standpunt aangaande internasionale konflik, waarin die belange van burgerlikes ter sprake gekom het, grootliks gelei deur die invloed van positivistiese denkwyses in 
die internasionale reg in die tweede helfte van die 19de eeu (kyk Raath \& Strydom, 1999:151).

- Die internasionale bemoeienis met die humanitêre belange van burgerlike bevolkings wat deur oorlog geraak is, het egter geleidelik veld gewen en wel tot so 'n mate dat die Haagse Konvensie, gerig op die humanisering van oorlog, in 1899 beslag gekry het (Raath \& Strydom, 1999:151-152). Die basiese beginsels van geregtigheid en billikheid teenoor burgerlikes het spoedig die positivistiese inslag van die internasionale reg getemper en rigtinggewend beïnvloed.

Die drie genoemde faktore het gedurende die loop van die AngloBoereoorlog in die Switserse politieke en regsisteem in spanning teenoor mekaar te staan gekom. Gevolglik is die Switserse neutraliteitspraktyk onder groot druk geplaas, sowel vanuit die invloedsfeer van Groot-Brittanje as van vooraanstaande Switserse leiersfigure wat die nuwe denke oor humanitêre oorlogvoering gepropageer het. Die gevolg was dat Switserland se regs- en politieke standpunte oor die oorlog in Suid-Afrika sterk deur genoemde faktore beïnvloed is. Die amptelike Switserse standpuntinnname oor die oorlog moet gesien word as 'n kompromie van genoemde drie oorwegings, wat in bepaalde opsigte 'n duidelik pragmatiese benadering oor internasionale geskille verraai het.

\section{Die amptelike standpunt van Switserland se bure}

Die uitbreek van die Anglo-Boereoorlog op 11 Oktober 1899 het die destydse wêreld met 'n skok getref. Die skokgolwe is vanaf Japan in die Ooste tot in die VSA in die Weste gevoel, en was derhalwe nie beperk tot die Britse Ryk nie. Daar was egter in die Britse Ryk en veral in lerland 'n besondere gevoel van wrewel as gevolg van die oorlog. Die uitbreek van die oorlog was die vonk wat nie slegs die spanning binne die Ryk tot breekpunt gedryf het nie, maar wat ook duidelik getoon het dat die Britse Gemenebes in 'n gevaarlike internasionale situasie beland het en dat 'n sterk anti-Britse houding ontwikkel het. Digters, skrywers en staatsmanne van wêreldstatuur, en veral die pers, het die publiek in beroering gebring. Ook die publiek het regerings onder druk geplaas om teen Brittanje kant te kies. Dit was veral dr. W.J. Leyds, Buitengewone Gesant en Gevolmagtigde Minister van die ZAR in Europa, wat hom in besonder bemoei het om die Europese regerings positief vir die 
Boeresaak te beïnvloed (Krüger, 1977:532); 'n saak waarvoor dr. H.P.N. Muller hom ook in 'n mindere mate beywer het.1

Die waarskynlike redes vir die anti-Britse houding, soos dit veral in Europa gemanifesteer het, was onder meer die die volgende:

- Die reaksie van geestelikes wat gekant was teen die Engelse liberalisme.

- Europese intelligentsia en veral Duitse geleerdes se siening van Engeland. Hierdie geleerdes wat aan invloedryke universiteite studeer het, het naamlik geleer om Engeland te minag. Volgens hierdie intelligentsia was Brittanje se posisie in die wêreld oorskat en hulle ideaal was om Engeland as wêreldleier te vervang.

Tot 1870 was Europa gewikkel in 'n reeks eksterne konflikte en interne rewolusies. Ná hierdie datum het groter stabiliteit en rustigheid ingetree, sodat Europa ná ongeveer 1880 ook onderwerp is aan die Industriële Rewolusie wat reeds teen die helfte van die eeu sterk inslag gevind het in Brittanje. Verskeie lande soos Duitsland en Frankryk het die oog gehad op oorsese kolonies, hoofsaaklik in Asië en Afrika, ten einde nuwe markte te skep wat as bronne vir grondstowwe kon dien. Hierdeur het Europa, as Brittanje se mededinger op territoriale en nywerheidsgebied, na vore getree. Die skep van markte en die ontginning van onverwerkte grondstowwe het beteken dat Europa vir homself in daardie gebied van Afrika en Asië wat nog onbeset was, kolonies moes vind. Amery merk in dié verband tereg op: "Consequently every attempt at territorial expansion by the European Powers met with British opposition. In some cases this opposition took the form of the assertion of a sort of 'Monroe doctrine' on behalf of the open market ... in others of hurried counter annexations" (Amery, 1907: V:53). Baie min anneksasies kon deur Europa uitgevoer word sonder die vrees vir Britse inmenging. Ná 1880 was daar altoos spanning in Europa aanwesig dat bedrywighede op handels- en koloniseringsgebied tot 'n Anglo-Europese krisis kon lei. Tot kort vóór die AngloBoereoorlog het krisisse soos die Fasjoda-episode, die probleme in Samoa en die Russiese betrokkenheid by Port Arthur 'n AngloEuropese krisis tot op die rand gevoer (Langer, 1972:691; Lepsius,

1 Leyds het nie gehou van Muller se betrokkenheid by die Boeresaak nie, omdat hy volgens Leyds op sy terrein oortree het. Hierdie negatiewe ingesteldheid het gelei tot 'n lewenslange vyandskap tussen dié twee persone (vgl. Spies, 1968:570-571). 
1923-1926:369-426). Die Europese moondhede het vanweë hulle agterstand op maritieme gebied minderwaardig gevoel teenoor Brittanje en het gretig gewag vir krake in die Britse verdediging sodat hulle dié Ryk kon aftakel. Die Boere van die twee Suiderlandrepublieke het gedoen juis dit wat Europa bang was om te doen, naamlik om die spreekwoordelike Britse leeu aan die stert te gryp.

Die historiese belangstelling van die Europeërs en die Europese koerante in die uitbreek van die Anglo-Boereoorlog was dus nie soseer ingestel op die "dapper" Boere nie, maar op die oorwinning van die vyand van Europa. Die "simpatieke" belangstelling in die stryd van die Boere was om verstaanbare redes hoofsaaklik dié van die Europese groot moondhede: Duitsland, Frankryk, Rusland en die VSA.

Die Transvaalse regering het op sy beurt belanggestel in die houding van die regerings van die groot moondhede (vgl. Scholtz, 1939). Dr. Leyds is daarom herhaaldelik om 'n mening gevra. Telkens was sy negatiewe versekering: "Duitschland sal niets doen. Frankryk sal gaarne Engeland moeilijkheden aandoen, maar op Frankryk valt niet te rekenen. Het is wisselvallig. Wel is er volgens algemene opinie kans dat Rusland zal optreden in Azië" (Leyds, 1938: Vol. I:174, 170). Dit was uitsluitlik die houding van die regerings van Duitsland, Frankryk en Rusland - en nie van enige ander wêreldmoondheid nie - wat die uitbreek van die AngloBoereoorlog kon verhoed of wat die verloop van die oorlog kon bepaal.

\section{Die Switserse posisie}

\subsection{Die amptelike Switserse standpunt}

Die beoordeling van die buitelandse beleid van die Switserse Republiek, hoewel eenvoudig, moet met groot omsigtigheid benader word. Die beginsel van neutraliteit waarop die Switserse beleid gebou is, is die produk van eeue se internasionale ervaring. In dié verband is die volgende drie beginsels tekenend van die Switserse beleid van neutraliteit:

- die Switserse verwerping van intervensie in buitelandse oorloë;

- die weiering om alliansies met buitelandse state te sluit; en

- die standpunt dat neutraliteit belangrik is vir die behoud van Switserse onafhanklikheid as 'n klein staat wat geen behoefte het om sy grense uit te brei nie. 
Anders as sy bure, het Switserland geen imperialistiese strewe in die tweede helfte van die 19de eeu gehad nie. Switserland se neutraliteit was nietemin 'n gewapende neutraliteit, met die doel om sy kosbare onafhanklikheid te beskerm.

Op die oog af wil dit voorkom asof so 'n buitelandse beleid maklik gehandhaaf sou kon word. So 'n beleid beweeg egter voortdurend op dun ys wanneer dit gekonfronteer word met 'n keuse oor moontlike betrokkenheid by militêre konflik. Sy optrede moet uiteraard dan van so 'n aard wees dat hy geloofwaardig en betroubaar bly. Tereg merk De Salis op: "Switserland realizes that in order to maintain its neutrality, it needs the confidence of other countries and therefore must be reliable and trustworthy" (vgl. De Salis, Henderson \& Henderson, 1971:37).

Met die uitbreek van die oorlog en ook met die verloop daarvan is die Switserse regering deur sy verteenwoordiger in Engeland, C.D. Bourcart, effektief op hoogte van sake gehou. Bourcart was egter glad nie objektief in sy beriggewing nie. Hy het tewens vanaf 1900 doelbewus probeer om sy regering pro-Brits in te stel.

Reeds op 6 Oktober 1899 het die Politieke Departement in Bern 'n telegram uit Londen ontvang met die nuus dat oorlog tussen Brittanje en die Boererepublieke onafwendbaar gelyk het. Ofskoon die Politieke Departement eers op 17 Oktober amptelik deur dr. Leyds en op 24 November deur die Britse gesantskap in Bern in kennis gestel is dat die Anglo-Boereoorlog op 11 Oktober 1899 uitgebreek het, het die regering reeds vóór hierdie datums geweet dat die stryd ontbrand het. (SBZ, PdB, 4049 (24.11.1899) en 4521 (24.11.1899)). ${ }^{2}$ Bourcart het in 'n brief van 14 Oktober sy regering oor die toestand ingelig. Hy het die oorsaak van die oorlog voor die deur van die Boere gelê en aangevoer dat Brittanje tot die oorlog gedwing is, aangesien hy sy oppergesag in Suid-Afrika moes handhaaf en Brittanje haar Kaapse koloniale besitting moes beskerm. Volgens hom was die blote bestaan van twee onafhanklike Boerestate op die grens van Britse gebied en die feit dat die Kaapse Eerste Minister, W.P. Schreiner, simpatiek teenoor Transvaal gestaan het, genoeg rede vir Brittanje om in te gryp (Davenport,

2 Afkorting vir die Sentrale Biblioteek Zürich, Protokoll des Bundesrates, Inskrywingsnommer 4049 (gedateer 17.10.1899). Protokol des Bundesrates, Inskrywingsnommer 4049, 17.10.1899, asook inskrywingsnommer 4521, 24.11.1899. 
1986:653-654). 3 Hy het verder gewaarsku dat dit 'n uitgerekte stryd sou wees indien die Boere nie binne afsienbare tyd tot oorgawe gedwing word nie. Op grond van hierdie moontlikheid en sy simpatie met die Engelse spruit sy vraag aan die begin van sy brief, of die Switserse regering nie dalk iets sou kon doen om 'n uitgerekte oorlog te voorkom nie (SAB, Bk: 2001/283: Brief: Bourcart Monsieur le Président (14.10.1899)).

Pas drie dae ná die uitbreek van die oorlog is die Switserse regering dus versoek om sy erkende neutraliteitsbeleid in heroorweging te neem. Hierna sou die Switserse regering telkens versoek word om in te gryp en as vredemaker op te tree. Uit die beskikbare bronne kan nie vasgestel word of die Bundesrat as uitvoerende gesag van 'n neutrale staat die versoek van sy verteenwoordiger enigsins oorweeg het nie. Die afleiding moet gemaak word dat hierdie saak aanvanklik op die agtergrond geskuif is. Nog voordat die nodige aandag aan die saak gegee kon word, het Bourcart egter laat weet dat die Britse regering enige tussenkoms sou weier (SBZ, PdB 1899: Brief: Bourcart - Müller (27.10.1899)). ${ }^{4}$ Op 2 November 1899 het hy in 'n verdere skrywe Londen se weiering om enige inmenging te duld, bevestig. Hy wys in dié skrywe daarop dat sy Nederlandse kollega hom meegedeel het dat hy die opdrag van sy regering ontvang het om sy invloed te gebruik ten einde die Britse regering tot bemiddeling deur Nederland te oorreed, maar dit is botweg geweier (SAB, Bk: 2001/283: Brief: Bourcart - Monsieur le Président (2.11.1899)).

Indien dié brief nie genoeg rede vir die Switserse regering was om op die kantlyn te bly nie, dan was dit Bourcart se pleidooi - wat eerder na 'n waarskuwing geklink het - dat die Switserse pers tot versigtigheid gemaan moet word, aangesien Switserland veel aan Brittanje verskuldig was. Hy wys die kabinet daarop dat hy hom nie deur die sentiment van die Boerevolk moet laat beïnvloed nie, maar realisties moet bly vir sover Switserland ekonomies van Brittanje afhanklik is. Volgens Bourcart was hierdie vriendskap van veel meer belang as dié van 'n republiek in die suide van Afrika (SAB, Bk: 2001/283, Brief: Bourcart - Monsieur le Président (2.11.1899)).

3 Vgl. Bern: Burenkrieg: 2001/283: Brief: Bourcart - Monsieur le Président, 14.10.1899, hierna afgekort as: SAB, Bk: 2001/283: Bourcart - Monsieur le Président (14.10.1899).

$4 \quad$ Afkorting wat gebruik word vir Protokol des Bundesrates, 1899: Brief: Bourcart Müller, 27.10.1899. 
Die vriendelike teregwysiging van Bourcart en die wete dat die Britte geen inmenging van 'n vreemde staat sou duld nie, het die Bundesrat waarskynlik beïnvloed om enige versoek tot intervensie te weier. Hierdie voorneme om nie in te meng nie, is nooit in ' $n$ amptelike besluit vervat nie en is ook nooit aan enige diplomatieke verteenwoordiger bekend gemaak nie. Dit het bloot 'n voorneme gebly en het eers as ' $n$ versoek om intervensie na vore gekom toe die Switserse konsul in Amsterdam, waarskynlik onder invloed van die sterk gevoel wat in Nederland vir die Boere aanwesig was, versoek het dat Switserland 'n militêre afvaardiging na die oorlogstoneel moet stuur. Hy pleit so: "Transvaal, Vrystaat und die Schweiz haben so manches gemeinsame, innige Liebe zum Vaterland, republikanische Institutionen, keine Eroherungspläne" (SAB, Bk: 2001/283, Brief: Schweizer Konsul - Bundespräsident (7.12.1899)).

Hierdie pleidooi dat Switserland moet help om 'n einde aan die oorlog te maak, het op hierdie stadium wel die Bundesrat se aandag verdien, want "der Bundesrat (hat) die Frage der Delegierung einer schweïzerischen militärmission nach dem südafrikanischen Kriegschauplatze schon in Erwägung gezogen und zum Schlusse gekommen ist, es sei von der Absendung von Offisieren nach Transvaal abzusehen" (SAB, Bk: 2001/283, Brief: Politisches Departement - Schweizer Konsul (9.12.1899)).

Dié antwoord verstrek geen rede vir die besluit nie, maar Bourcart se reeds gemelde brief het waarskynlik grootliks tot die besluit bygedra. 5 Die algemene houding van die buitelandse moondhede aan die begin van 1900 was een van groot belangstelling in die oorlog, maar geensins om daarby direk betrokke te raak nie (SAB, Bk: 2001/283, Brief: De Claparède - Bundespräsident, Wien (10.12.1900)). Die Boererepublieke, bewus van die feit dat hulle geen buitelandse hulp kon verwag nie, en gekonfronteer met die harde feite van die slagveld, het op 5 Maart 1900 'n telegram aan Brittanje gestuur. ${ }^{6}$ Op twee voorwaardes was Transvaal en die

5 Dié afleiding kan gemaak word aangesien Bourcart 'n groot invloed op die regering gehad het. Sy mening is hoog aangeslaan.

$6 \quad$ Na die aanvanklike sukses van die Boeremagte met die hoogtepunt tussen 1015 Desember 1899 op die Natalse grens (Colenso: 13-14 Des. 1899), die wesgrens (Magersfontein: 12 Des. 1899) en die suidgrens (Stormberg: 10 Des. 1899), het Engeland herstel, groot magte gemobiliseer en toe teruggeveg. Uiteindelik is die Boere verplig om die beleg van Ladysmith op te hef, generaal Cronje is by Paardekraal op 27 Februarie 1900 met 4048 man gevang en groot 
Vrystaat bereid om vrede te maak: die Republieke moes as soewereine, onafhanklike state erken word en volle amnestie moes verleen word aan die Britse onderdane wat vir die Boere geveg het, naamlik dié uit Kaapkolonie en Natal. Hiervoor was Brittanje nie te vinde nie.

Enkele dae later het presidente Kruger en Steyn alle geakkrediteerde konsuls van buitelandse moondhede versoek om as bemiddelaars tussen die vegtende partye op te tree om 'n einde aan die oorlog te maak. Die versoek is aan 'n hele aantal Europese state gestuur, onder andere aan Duitsland, Frankryk, Holland en Switserland, sowel as aan die Verenigde State van Amerika.

Aangesien die Duitse konsul in Pretoria, Biermann, ook Switserland verteenwoordig het, het hy aan sy regering in Berlyn die volgende telegram gestuur:

Auf Ersuchen der hiesigen (sic) Regierung melde ich, dass die Regierungen der Republiken um die freudschäfteliche Vermittlung der kaiserlichen Regierung zur Herstellung des Friedens bitten. Gleiches Ersuchen ist den Vertreten anderer Mächte zungegangen (sic). Die regierung bittet ferner, der Osterreichischen und Schweizer Regierung die gleiche Bitte zu übermitteln (SBZ, Berichte des Bundesrates, 1900: 380). ${ }^{7}$

Terwyl die state nog aan die versoek geherkou het en gewag het dat iemand die inisiatief moes neem, het Salisbury reeds op 11 Maart die Republieke se versoek geweier. Ofskoon die inhoud van sy antwoord wêreldwyd bekend gemaak is, het die Amerikaanse president, die Republikein William McKinley, onder die invloed van die Kruger-Steyn-telegram, Brittanje sy diens aangebied om as bemiddelaar op te tree. Die besliste antwoord van Londen aan die Amerikaanse verteenwoordiger, naamlik dat Brittanje geensins belangstel in die bemiddeling van die VSA of enige ander moondheid nie, was 'n duidelike wenk aan die adres van enige proBoergesinde regering om hom nie met die saak in te meng nie.

verwarring en oorlogsvrees het die Boere oorval. ' $n$ Vredesaanbod is gemaak en gestuur op grond van die besef dat Bloemfontein en daarna Pretoria in Britse hande kon val. Vir algemene besonderhede oor die verloop van die stryd tot Februarie 1900, kyk Breytenbach (1969-, vol. I-IV).

$7 \quad$ Kyk ook Lepsius, Mendelssohn-Bartholdy en Thimme (1923-1926: Vol XV:524).

Telegram: Biermann - das Auswärtige Amt, 10.3.1900. 
Die Bundesrat is deur sy verteenwoordigers deeglik ingelig dat Europese magte na hierdie antwoord om verskillende redes besluit het om nie by die oorlog betrokke te raak nie. Die Bundesrat het op aandrang van die Politieke Departement besluit om ook nie verdere aandag te skenk aan die versoek van die Boerepresidente nie (SBZ, PdB 1900:No. 1147). Die Bundesrat se antwoord via die Switserse gesant in Berlyn aan Kruger en Steyn, lui soos volg:

Der schweizerische Bundesrat hatte gern bei einer freundschaftlichen Vermittlung mitgewirkt, um weiterem Blutvergiessen ein Ende zu machen. Nachden aber die Präsidenten der beiden südafrikanischen Republiken bei der grossbritannischen Regierung direkt Schritte getan haben, um auf der bekannten Basis Frieden zu schliessen, und die grossbritannische Regierung sich hierauf ablehnend verhalten hat; nachdem ferner die grossbritannische Regierung dem Washingtoner Kabinett erklärt hat, es liege nicht in ihrer Absicht, die Vermittlung irgendwelcher Macht anzunehmen, muss auch der schweizerische Bundesrat zu seinem Bedaurern darauf verzichten irgendwelche Schritte im Sinne des Ansuchens der Präsidenten der sudafrikanischen Republiken zu tun, und es bleibt ihm unter den obwaltenden Unständen nichts anderes übrig, als seinem lebhaften Wunsche Ausdruck zu geben, es möchte den Kriegsführenden in nicht zu ferner zeit gelingen, einen für beide Teile ehrenvollen Boden der Verständigung zu finden (Von Salis, 1903-1904: Vol. V: 663). ${ }^{8}$

Hierdie antwoord het die Switserse gesant, dr. J.B. Pioda, verkeerd bewys toe hy twee maande tevore 'n sekere G.H. Kimberley van New York, wat versoek het dat Switserland onverwyld as bemiddelaar moet optree (SAB, Bk: 2001/284, Brief: Kimberley Pioda (27.1.1900)), geantwoord het dat sy regering beslis en graag as bemiddelaar sou optree, maar "[un]fortunately the good will of my Government is hardly of any use as long as the two countries are not seeking for an intervention of another country" (SAB, Bk: 2001/284, Brief: Pioda - Kimberley (1.2.1900)).

Aangesien die regerings van die Westerse moondhede deeglik bewus was van die uitbreek en verloop van die oorlog, het hulle gedurende 1900 en 1901 toenemend kennis geneem van die ontwikkeling van die stryd. Hierdie kennisname het momentum gekry met die bekende Swart Week van 10-15 Desember 1899. Daarna sou dit grootliks generaal De Wet se militêre genialiteit wees 
wat simpatie vir die Boeresaak in Europa opgewek en behou het (Spies, 1946:06). Die ontbering van die vroue en kinders in die konsentrasiekampe sou tydens die laaste fase van die oorlog die noodsaak beklemtoon dat die oorlog beëindig moet word. Stemme wat gevra het dat die oorlog gestaak moet word, is geaktiveer deur die bloedvergieting tydens die eerste helfte van die oorlog, maar daarna het die lyding van die vroue en kinders die mensdom se gevoelens van simpatie versterk.

Omdat gewone verenigings, organisasies en burgers nie die diplomatieke kanale gehad het om Brittanje om die konferensietafel te ontmoet en tot vrede te dwing nie, moes regerings versoek word om dit te doen. Die Switserse regering is uiteraard as die ideale bemiddelaar beskou, omdat dié regering uitgesproke neutraal was. Die Bundesrat is gevolglik in die loop van die oorlog oorval met versoeke om tussenbeide te tree of om Brittanje te oorreed om die oorlogvoering te staak. Sodanige versoeke het gekom van binne- en buitelandse vredesverenigings, Boerekomitees, kerklike organisasies en persone in hulle private hoedanigheid.

Die eerste in 'n reeks versoeke tot intervensie aan die Bundesrat was in Maart 1900. Hierdie versoeke het uit die Franssprekende kanton Vaud gekom toe die Switserse vredesburo in hierdie kanton die Bundesrat versoek het om, wanneer die geleentheid hom voordoen, voorspraak te doen by ander moondhede om die oorlog te beëindig (SAB, Bk: 2001/284, Brief: Protokollführer - Schweiz, Friedesverein (19.3.1900)). Die versoek is deur 1574 persone onderteken (SAB, Bk: 2001/284, Brief: E. Ducommum - Bundesrat (16.3.1900)). 9

Drie weke later stuur die "Deutschen Centrale für Bestrebung zur Beendigung des Burenkrieges", met hoofkantoor in München10, 'n brief aan Heller, die president van die Nationalrat, met die versoek dat die Switserse parlement die inisiatief moet neem om die neutrale regerings wat die Haagse konvensie onderteken het, te laat saamwerk om vrede in die Republieke te bewerkstellig. Die versoek is deur Heller na die kabinet verwys (SBZ, PdB: 1625 (12.4.1900).

$9 \quad$ Vir die brief, kyk SBZ, PdB, 1625 (19.3.1900).

10 Hierdie Duitse komitee wat sy ankers in die Duitse vredesvereniging gehad het, het groot en belangrike werk in Duitsland gedoen. 
Op 15 Mei 1900 het die Internasionale Vredesburo 'n soortgelyke versoek gerig (SBZ, PdB: 2225 (18.5.1900)). ${ }^{11}$ Die Buro het die ondertekenaars van die Haagse ooreenkoms daaraan herinner dat hulle hulle verbind het tot Artikel 1: "D'employer tous leurs efforts pour assurer le reglement pacifique des conflits internationaux" (vry vertaal: dat die ondertekenaars ooreengekom het om al hulle invloed te gebruik te einde 'n vreedsame oplossing in internasionale geskille (dispute) te vind). Hulle wys ook daarop dat volgens Artikel 3 , 'n buitelandse moondheid kan aanbied om as arbiter in geskille op te tree en dat dit nie as 'n negatiewe daad beskou sal word nie. Voorts word gewys op die rol van 'n arbiter, soos vervat in Artikels 3.5. Die brief geskryf onder die vaandel van humaniteit, smeek die Switserse regering ten slotte om 'n positiewe reaksie (SAB, Bk: 2001/284, Brief Bajer e.a. - Monsieur le Prémier Ministre (15.5.1900)).

Die stemme wat opgegaan het ten gunste van intervensie ter wille van die beeïndiging van die bloedvergieting, het ná Mei 1900 tydelik dowwer geword. Slegs die stemme van Leyds wat protes aangeteken het teen Roberts oor sy minagting van die Volkereg12 en dié van die Ligue belge des droits de 'I homme wat Switserland op 12 September 1901 versoek het om in te gryp,13 is in hierdie verband gehoor. Die Bundesrat het van hierdie versoeke bloot kennis geneem, dit nie eens bespreek nie en as ad acta beskou. Die Britse antwoord aan McKinley was steeds die rede vir Switserland se koue en afsydige houding.

Hierdie houding van die Bundesrat en die feit dat daar 'n insinking in die oorlogsaktiwiteite ingetree het nadat Johannesburg op 31 Mei 1900 binnegeval is en Pretoria op 5 Junie ongehinderd deur lord Roberts se magte ingeneem is, was waarskynlik die primêre redes vir die tydelike swye. In die Vrystaat het generaal Christiaan de Wet egter na die besetting van die republikeinse hoofstede die aandag begin trek vanweë sy hernieude aktiwiteite en suksesvolle werwing van burgers. Die stryd het nou 'n nuwe aard verkry: van stellinggevegte is afgesien en guerilla-oorlogvoering het ingetree.

11 Kyk ook SAB, Bk: 2001/284, Brief: Fr. Bajer, E. Ducommum, Henri Morel, dr. Ludwig Stein, Emile Arnaud - Monsieur le Prémier Ministre (15.5.1900)). Affaires Etranèges (22.91901). Kyk ook SBZ, PdB, 3980 (27.9.1901). 
Die hernieude militêre aksies in die Vrystaat was vir Roberts baie ongeleë, veral nadat sy magte in September 1900 daarin geslaag het om die Transvaal-Portugese grens te bereik en die politieke en militêre ineenstorting van sy vyand vir hom na 'n voldonge feit gelyk het (Pienaar, 1975:59-164). Roberts het gevolglik besluit om al sy aandag op De Wet toe te spits ten einde hom te vang en onskadelik te maak. Die wedloop wat hierna deur een na die ander belangrike Britse aanvoerder begin is om De Wet in die hande te kry, is met ingehoue asem deur baie mense ver buite die grense van SuidAfrika gevolg (Pienaar, 1975:172-236; Pretorius, 1976). De Wet se taktiek van toeslaan en terugval het spoedig bykans al die Boerekommando's se nuwe wyse van oorlogvoering geword. Dit was so suksesvol dat die stryd vir Brittanje baie uitputtend en uitgerek geword het. Ander metodes, benewens die geweerloop, moes derhalwe gevind word om die Boere tot oorgawe te dwing. Lord Kitchener wat lord Roberts aan die einde van November 1900 opgevolg het, het aan die begin van 1901 'n nuwe strategie begin toepas. Dit het bestaan uit drie maatreëls om die Republieke in 'n groot wildernis te omskep, naamlik deur dorpe en plaaswonings te verwoes, kosvoorrade soos graan en vee te vernietig; sogenaamde "Refugee Camps",14 oftewel konsentrasiekampe op te rig waarin die vroue en kinders van die vegtende linies saamgehok is en omvattende blokhuislinies te bou (vgl. Britse Blouboek, Cd. 524).

Die buitewêreld het met verontwaardiging kennis geneem van die toestande, veral ten opsigte van die vroue en kinders in die konsentrasiekampe. ${ }^{15}$ Nuwe, maar insgelyk dringender, stemme is oor hierdie saak gehoor. Hierdie stemme kon nie soos in die geval van die beroep op die voorkoming van bloedvergieting, deur Switserland geïgnoreer word nie. Die bloedvergieting wat op daardie stadium plaasgevind het, was merendeels 'n gevolg van die heersende omstandighede van veral die vroue en kinders in die konsentrasiekampe; derhalwe sou nóg Switserland nóg enige ander moondheid daarteen protesteer. 'n Reaksie op die bloedvergieting sou 'n reaksie teen die oorlog wees - iets waarvoor geen moondheid en Switserland allermins lus gehad het nie. Met die oprigting van die konsentrasiekampe het die situasie egter verander.

14 Vir besonderhede oor hierdie aspek waarmee op 25 November 1899 met die afbrand van huise op Derdepoort naby Mafeking begin is, kyk Kriel (1956) en Otto (1954).

15 Die haglike omstandighede in die kampe was die direkte gevolg van Kitchener se konsentrasiekampproklamasie van 21.12.1900. Kyk Amery (1905:86). 
Dit was immers moeilik om die oë te sluit vir die ellendes hiervan, veral soos dit deur Emily Hobhouse en ander pro-Boereverenings aan die wêreld voorgehou is.

Dit was nie vanweë druk via die nuusmedia, kerklike kringe, 'n legio pro-Boereaksies of die reaksie van die gewone burgerlike bevolking wat die regerings met nuwe oë na die oorlog in Suid-Afrika laat kyk het nie. Die rede waarom regerings nou wel begin belangstel het, word miskien die beste saamgevat deur die Duitser $\mathrm{H}$. Schowalter in sy voorwoord tot sy Amtlich Berichte und andere Urkunden. Schowalter (1902:voorwoord) voer aan dat

... die ganze zivilisierte Welt (wünscht) mit Verleugnung ihres eigenen Vorteils im Internesse der Menschlichkeit den Frieden, weil sie Aussichten aufland und Besitz in Südafrika nicht um den Preis der Vernichtung der Hälfte eines Kulturvolkes, oder gerade seiner besseren Elemente und seiner edelsten Eigenschaften erwerben will.

Die Switserse regering was, soos ook ander Europese regerings, bereid om te luister na die saak van die vroue en kinders in die konsentrasiekampe (Schowalter, 1902: Voorwoord). Die Switserse regering was op amptelike vlak en via die Duitse konsulaat in Pretoria deeglik op hoogte gehou van die toestand van die Boeregesinne in die sogenaamde vlugtelingkampe (SBZ, PdB: 3456 (13.8.1901)).

Op 10 September 1901 het Leyds en die ander Boere-gevolmagtigdes die permanente beheerliggaam van die arbitrasiehof in Den Haag versoek om stappe te doen om Brittanje te verplig om die Suid-Afrikaanse saak aan arbitrasie te onderwerp. Die hof moes besin oor die oorsake van die oorlog en 'n mening uitspreek oor Brittanje se wyse van oorlogvoering. Daar is nie gehoor gegee aan dié versoek nie, omdat die hof hom nie bevoeg geag het om die saak te hanteer nie. Die hof het hom beroep op Artikel 27 van die Haagse ooreenkoms van 29 Julie 1899.16

Die beslissing is mondeling aan Leyds oorgedra, waarop die versoek aan ander regerings, waaronder die Bundesrat, gerig is. Die Politieke Departement het op 21 Januarie 1902 by die Bundesrat voorgestel dat die saak bloot as ad acta beskou word, aangesien Brittanje se houding oor intervensie bekend was en reeds in 1900 
nie gehoor gegee is aan 'n soortgelyke versoek, naamlik dié van Kruger en Steyn nie. Die Bundesrat was dit met hierdie voorstel egter nie eens nie en het aan sy verteenwoordigers in Parys, Berlyn, Rome en Wenen opdrag gegee om inligting te verskaf oor die houding van die regerings oor hierdie aangeleentheid. Die inligting wat bekom is, was dat die groot magte die versoek geweier het. Net Nederland en Portugal het positief gereageer op die versoek, maar Brittanje het kategories geweier om gehoor te gee aan die versoek en was steeds in hierdie opsig onversetlik.

Juis in hierdie tyd, dit wil sê die begin van 1902, was daar baie woelinge en is druk op Brittanje uitgeoefen om uit die Republiek te onttrek. Dat Brittanje egter self die oorlog tot 'n oorwinning wou voer en steeds nie van plan was om die saak aan arbitrasie te onderwerp nie, blyk duidelik uit lord Landsdowne se antwoord aan baron Gericke: "It is not their (die Britse regering se) intention of (allowing) any foreign Power in the South African war." En verder: "In these circumstances His Majesty's Government have decided that if the Boer leaders should desire to enter into negotiations for the purpose of bringing the war to an end, those negotiations must take place, not in Europe, but in South Africa" (Britse Witskrif, Africa No. 1 (1902), Brief: The Marquess of Landsdown - Baron Gericke (29.1.1902)).

By die behandeling van al die versoeke om tussenkoms of intervensie kon die Bundesrat hom laat lei deur die houding van die ander state. Dit moet toegegee word dat dit vir Switserland polities totaal onwys sou gewees het om alleen en sonder hoop op sukses as tussenganger te funksioneer, veral omdat die Britse regering sy standpunt teenoor enige tussenkoms meermale duidelik gestel het. 'n Poging van Switserland wat hom uit sy posisie van neutraliteit sou stel, sou sekerlik die spanning tussen die twee lande vergroot het.

\subsection{Die Manzoni-Gobat-mosie in die Nationalrat}

'n Private mosie uit die geledere van die Nationalrat (Volksraad) en van twee kantonale regerings sou die Bundesrat egter in die noute dryf. Die Bundesrat is tot op die rand van 'n ernstige interne krisis gebring, aangesien die mosie in die Nationalrat, indien dit deurgevoer sou word, ernstige politieke gevolge kon hê. Die mosie in die Nationalrat het algemeen as die Manzoni-Gobat-mosie bekend gestaan.

Dr. Romeo Manzoni, 'n Italiaanssprekende Switser, is in 1847 in die dorpie Arogno in Maroggia gebore. Hier was hy eienaar en direkteur 
van die Internasionale Instituut. Op 42-jarige leeftyd raak hy betrokke by 'n opstand teen die Grootraad en regering van die kanton Tessin. In hierdie opstand op 11 November 1890 is die regeringsgeboue in Bellinzona deur die volk beset en 'n sekere Rossi, 'n lid van die regering, is doodgeskiet. Hierop het die Bundesrat 'n kommissie van ondersoek aangestel wat hulle bevindings op 3 November aan die staatsprokureur, Scherb, oorhandig het. Op 11 Desember het Scherb 'n klag gelê teen 21 mense wat verantwoordelik sou wees vir die opstand - Manzoni was een van hierdie mense (Von Salis, 1903: Vol. I:143). Die gebeure het van Manzoni 'n bekende gemaak. Later het hy die Tessin-kanton in die Nationalrat verteenwoordig.

Dr. Charles Albert Gobat, 'n Franssprekende Switser, is op 21 Mei 1834 in die dorpie Tramelan in die Bernse Jura gebore. Hy het besondere invloed uitgeoefen as Direkteur van Onderwys van die kanton Bern (1882-1906) en as Direkteur van die internasionale Vredesburo in Bern. Onder sy leiding het die skole in die kanton Bern 'n groot finansiële bydrae tot die oorlog gelewer. Hy betree die aktiewe politiek in 1884 toe hy as lid van die Nationalrat verkies is. Hy bly lid van hierdie huis tot in 1890 waarna hy lid van die Ständerat (1890-1914) word. Hy was ook as geskiedskrywer bekend en in 1902 is die Nobelprys vir vrede aan hom toegeken (kyk Anon., 1950:609).

Hierdie twee persone, albei van die Nationalrat, het op 8 Desember 1900 saam met 36 mede-ondertekenaars die volgende mosie ingedien:

Der Schweizerische Nationalrat richtet an das englische Volk und Parlement, sowie an die europaïschen Parlamente, einen dringenden Aufruf, dass die Transvaal-Frage nach den Grundsäzten internationaler Gerechtigkeit durch ein Schiedsgericht erledigt werde (SBZ, Verhandlung der Bundesversammlung, Des. 1900, Nr. 52). ${ }^{17}$

17 Kyk ook SBZ, PNR: Des. 1900: inskrywing 32. Die ondertekenaars uitgesonderd Manzoni en Gobat was die volgende: Baldinger (Aargau); Bühler (Graubünden); Cavat (Waadt); Curti (Zürich); Decoppet (Waadt); Decurtins (Graubünden); Desfayes (Wallis); Dinichert (Freiburg); Dinkelmann (Bern); Eingenmann (Thurgau); Folletête (Bern); Fonjallaz (Waadt); Gschwind (Baselland); Hilty (St. Gallen); Hochstrasser (Luzern); Hoffmann (Thurgau); Jäger (Aargau); Lagier (Waadt); Locher (Zürich); Ming (Obwalden); Moser (Bern); Paillard (Waadt); Pioda (Tessin); Risch (Graubünden); Rusconi (Tessin); Scherrer-Füllemann (St. Gallen); Schmid (Uri); Sonderegger (Innerrhoden); 
As die uitgangspunte en politieke sentimente van die persone wat die mosie onderteken het, ontleed word, is dit duidelik dat hulle bedoeling opreg was. Sestien van die ondertekenaars kan as links beskryf word, sewe neutraal, vyf regs en agt uit ander groepe. Hulle was afkomstig uit feitlik elke kanton en het al vier die Switserse tale verteenwoordig.

Die opstellers van die mosie het gemeen dat Switserland as neutrale land en met 'n beroep op Artikel III van die Haagse arbitrasiehofbepalings, ${ }^{18}$ 'n positiewe voorstel sou waag om 'n vreedsame oplossing te bewerkstellig. Hulle was daarvan oortuig dat so 'n beroep op Brittanje nie die Switserse neutraliteit in gedrang sou bring nie, aangesien die mosie nie die Britse krygsmetodes veroordeel het nie en geen standpunte vir of teen die oorlog ingeneem is nie.

Toe Bourcart in die Londonse koerante van die mosie lees, het hy dadelik 'n telegram aan sy regering gestuur om hulle te waarsku dat die mosie in Brittanje "nur böses Blut machen und keinerlei praktische Resultate erreichen (würde)" (SAB, Bk: 2001/284: Telegram: Bourcart - Hauser (10.12.1900)). In 'n opvolgbrief stel hy dat die Engelse koerante die saak oordryf en dat dit ernstige probleme vir die Brits-Switserse verhouding kon skep. Hy vra dat die parlement van die saak moet afstap, aangesien die gevolge van betrokkenheid nie die poging werd sou wees nie (SAB, Bk: 2001/284: Brief: Bourcart - Bundespräsident (10.12.1900)).

Ook in die Switserse pers het die mosie wye en uiteenlopende reaksie uitgelok. Die belangrikste hiervan was waarskynlik Heinrich Angst se hoofartikel in die Züricher Post (11.12.1900). Angst het onder andere beweer dat die ondertekenaars die verkeerde tyd gekies het om Brittanje te konfronteer, aangesien die oorlog na aanvanklike mislukking, op daardie stadium in Brittanje se guns verloop het en dat die Britse parlement reeds projekte in die oog gehad het om die oorlog bevredigend te beëindig. Uhl beweer dat hierdie artikel onder lede van die Nationalrat gesirkuleer is en 'n

Steiger (Bern); Thélin (Waadt); Triguet (Genf); Vincent (Genf); Vital (Graubünden); Vogelsanger (Zürich); Wullschleger (Basel) en Zürcher (Zürich). hulle goeie diens aan strydende state te bied met die oog daarop om vrede te bewerkstellig. Die uitoefening van hierdie reg sou nie deur die strydende partye as 'n negatiewe daad gesien word nie. 
belangrike negatiewe implikasies vir die saak van die Boere gehad het (Uhl, 1961:100).

Die mosie het egter ' $n$ veel groter gefladder in die nasionale as die internasionale duiwehok veroorsaak. Dit was 'n buitengewone mosie in die sin dat dit gerig is aan die Nationalrat en nie aan die Bundesrat, as beoefenaars van die buitelandse beleid nie. Die Nationalrat is volgens die mosie die taak opgedra om met die Britse parlement te onderhandel. Behalwe dat die mosie dus spanning tussen Brittanje en Switserland bewerkstellig het, het dit veral spanning in die parlement gebring, want indien die mosie ná bespreking aanvaar sou word, sou dit beteken dat die Nationalrat die terrein van die Bundesrat betree (kyk Müller, 1944:98). Die dilemma waarin die mosie die parlement geplaas het, was dus ernstig van aard.

Oudkabinetslid Frey het dan ook in duidelike taal standpunt ingeneem met 'n verklaring in die Basler National Zeitung (11.12.1900). Hy het die mosie bestempel as "durch und durch verfassungswidrig". Juis hierom moes dit "mit der grössten Energie bekämpft werden". Hy het ook daarop gewys hoe 'n intervensieversoek aan die Nationalrat in stryd met Artikel 102 Zi ff 8 van die grondwet sou wees. 'n Intervensieversoek sou die taak van die Bundesrat wees. Hy het verder ook daarop gewys dat die grondwet ook nie die Nationalrat die reg gee om met die parlement van 'n ander land oor sy interne politiek in gesprek te tree nie. Slegs wanneer 'n toestand van anargie sou heers en die staat moontlik daardeur geruïneer kon word, sou 'n praktiese geleentheid geskep kon word waar óf die Nationalrat óf die Ständerat op eie inisiatief buitelandse politiek kon bedryf (Basler National Zeitung: 11.12.1900).

Die omstrede vorm van die mosie is in Das Vaterland beskryf as "ohne Präzedenzfall (in) unserer parlamentarischen Geschichte" (Das Vaterland: No. 283, 1900). Die Basler National Zeitung het die kruks van die probleem in 'n hoofartikel so saamgevat: "So sehr man aber im innersten Grunde des Herzens mit dem genannten Antrag sympathisieren mag, so darf doch nicht verschwiegen werden, dass derselbe nicht nur ein ungewöhnliches, sondern auch ein höchst impolitisches Vorgehen darstelt" (Basler National Zeitung: 11.12.1900).

In dieselfde trant en uit vrees dat buitelandse moondhede dalk deur die aanneem van die mosie aangemoedig kon word om in te meng in die Switserse vlugteling- en asielvraagstuk, het die hoof van die 
Politieke Departement - in opdrag van die Bundesrat - vir Manzoni en sy mede-ondertekenaars versoek om die mosie terug te trek (SAB, Bk: 2001/283. Erklärung des Bundesrates betreffend die Motion Manzoni-Gobat).

Met groot moeite is daarin geslaag om die ondertekenaars te beweeg om hulle versoek op grondwetlike gronde terug te trek (SBZ, PNR: Des. 1900, inskrywing 651). Op 18 Desember het Manzoni, Sonderegger, Folletête en Curti teruggetrek (SBZ, PNR: Des. 1900, inskrywing 367) en twee dae later die res (SBZ, PNR: Des. 1900, inskrywing 380). In 'n verklaring, ná die terugtrekking, word dit duidelik gestel dat hulle bewus was van die positiewe gevoel van die meerderheid Switsers, maar dat hulle nie langer kon versuim om ag te gee op die wens van die meerderheid van hulle kollegas in die Raad nie. 19

Hiermee was die posisie wel vir die Switserse regeringstelsel gered, maar die behoefte om die boodskap van die mosie uit te dra het steeds bestaan. Die probleem is daarop aan die Interparlementêre Vereniging oorgedra. 20 Gobat, as voorsitter van die Switserse tak, is die taak opgedra om 'n skrywe aan goedgesindes in die Britse parlement te rig. In sy brief wys hy op die bona fides van die Switserse volk en op hulle sentimente waaronder dié vir Engeland, maar dan sekerlik ook hulle meegevoel met 'n klein, vaderlandsliewende volk soos dié van die Suid-Afrikaanse Republieke.

Hierdie gevoel, verwyderd van enige eensydige standpunt of antipatie, is deur die brief aan die Britse volk en die lede van die parlement op 'n duidelike wyse gestel. Die gedagte "dass in Südafrika die Waffen niedergelegt und die werke des Friedens für

19 Die volledige verklaring soos opgeneem in onder andere Der Bund van 2122.12.1900 lui soos volg: "Der scweiz. BR hätte gern bei einer freundschaftlichen Vermittlung mitgewirkt, um weiterm Blutvergiessen ein Ende zu machen. Nachdem aber die Präsidenten der beiden südafrikanischen Republiken bei der grossbritanischen Reg. sich hierauf ablehnend verhalten hat, nachdem ferner die grossbritanische Reg. dem Washingtoner Kabinett erklärt hat, es liege nicht in ihrer Absicht, die Vermittlung irgend welcher Macht anzunehmen, muss auch der schweiz. BR zu seinem Bedaurn darauf verzichten, irgend welche Schritte im Sinne des Ansuchens der Präsidenten der südafrikanischen Republiken zu tun, und es bleibt inm unter den obwalten Umständen nichts anderes übrig, als seinem lebhaften Wunsche Ausdruck zu geben, es möchte den Kriegführenden in einer nicht zu ferner Zeit gelingen, einen für beide Teile ehrenvollen Boden der Verständigung zu finden."

20 Dit was 'n vereniging met die doel om idees en begrip op interdepartementele vlak, dus tussen volk en volk, uit te ruil. 
dauernd wieder aufgenommen werden können" is by wyse van dr. Gobat se brief dus wel op 'n nie-amptelike vlak oorgedra (Der Bund: 26.12.1900).

\subsection{Mosies uit die kantons Bern en Solothurn}

'n Jaar ná die Manzoni-Gobat-mosie het die parlement weer voor 'n dilemma te staan gekom. Die bekendwording van die toestande in die konsentrasiekampe teen die einde van 1901 het 'n vlaag van simpatie in Switserland tot gevolg gehad. Hierdie gevoel van simpatie het onder andere uitdrukking gevind in 'n reeks kantonale mosies, wat opnuut probleme vir die Bundesrat veroorsaak het.

Die eerste van hierdie mosies is op 18 November 1901 deur die sosialis, Karel Moor, opgestel en op 19 November 1901 tydens die tweedaagse sitting van die Bernse Grootraad by die Raad ingedien.21 Die mosie, die werk van die sosialiste, is aanvanklik deur die liberales teëgestaan, maar is later deur die steun van die konserwatiewes en 'n klompie onafhanklikes deurgevoer. Die oorspronklike mosie lui soos volg:

Der Grosse Rat beauftragt den Regierungsrat, gemäss Art. 93 der Bundes-verfassung beim Bundesrate das Initiativbegehren zu stellen, die Bundesregierung möge bei den übrigen Regierungen gemeinsame Schritte anregen, um die britische Regierung zu veranlassen, der unmenschlichen, völkerrechtswidrigen Art der Kriegsführung in Südafrika und dem Elend der unglücklichen Burenfrauen und -Kinder in den Konzentrationslagern ein Ende zu bereiten (SBZ, TdGR: 20.11.1901: 536). ${ }^{22}$

Die mosie wat onderteken is deur twaalf kollegas van Moor is ná indiening in die loop van die daaropvolgende dae deur 'n verdere vyf-en-vyftig raadslede onderteken.

Hierdie mosie is druk bespreek in die pers, deur die regering en die Bernse volk. Daar is gevoel dat die deel van die mosie wat ' $n$ oordeel uitspreek oor die wyse waarop Brittanje oorlog voer, dalk aanstoot kon gee. As gevolg van druk, ook van regeringskant, om

21 Karel Moor, gebore 1852, was leier van die sosiaal-demokrate in die Bernse Grootraad, waar hy Lorraine-Breitenrain vanaf 28.2.1897 tot 31.5.1906 en weer vanaf 8.5.1910 tot 31.5.1922 verteenwoordig het. Hy was ook redakteur van die Berner Tagwacht, 'n koerant wat die Boere simpatiek gesind was (SAB, Archiv des historischen Vereins des kantons Bern, Vol. 59). 
van die mosie af te sien, het Moor daarop met vier van sy sekondante wat verskillende partye verteenwoordig het, te wete burgermeester Steiger, Lohner, Dürrenmatt en dr. Jobin, 'n lang bespreking gevoer oor die inhoud en die wenslikheid van die mosie. Die konsensus wat hulle bereik het, was dat die mosie dringend nodig was, maar in 'n minder aanvallende vorm bewoord moes word sodat die Switserse verhouding met Brittanje en sy neutraliteit nie in die gedrang gebring sou word nie. Daar is ooreengekom om die mosie te verander om soos volg te lees: "Die Bundesregierung möge bei den ausländischen Regierung gemeinsame Schritte anregen, um die britische Regierung zu veranlassen, dem Elend der unglücklichen Burenfrauen und Kinder in den Konzentrationslagern ein Ende zu bereiten" (SBZ, TdGR: 10.10.1901:510).

Deur die woordkeuse en formulering te verander, het die dreigende toon van die oorspronklike mosie verdwyn en het dit humanitêre oorwegings as uitgangspunt gestel. Hierdeur kon 'n kompromie met die Switserse regering aangegaan word. Deur die gedeelte oor die oorlog in die mosie weg te laat en die deel oor die konsentrasiekampe te behou, het die regering geen verdere druk op die mosiestellers geplaas om af te sien van hulle voorneme om hulle op Artikel 93 reël 2 van die grondwet te beroep nie. ${ }^{23}$

Die les wat Moor en sy vriende uit die Manzoni-Gobat-mosie geleer het, was om nie deur 'n bepaalde huis nie, maar met die parlement as sodanig te werk. 'n Ontleding van die mosie gee blyke dat Moor dit in die Bernse Grootraad goedgekeur moes kry, waarna die Parlement, as hoogste gesag, uit hoofde van Artikel 93 gedwing sou word om die mosie in albei sy huise, te wete die Ständerat en Nationalrat, te bespreek. Indien die mosie in albei huise aanvaar sou word, sou die Parlement aan die Bundesrat wat aan die parlement verantwoordelik is, maar insgelyks ook die buitelandse politiek bedryf, opdrag gee om die nodige stappe by buitelandse regerings te doen om Brittanje te oorreed om 'n einde aan die ellende in die konsentrasiekampe te maak. Op hierdie stadium was daar 117017 gevangenes in die konsentrasiekampe waarvan 17688 mans was (Britse Blouboek, Cd. 902). Die simpatie het nie soseer by die mans dit 'n byna vergete artikel is wat baie min toegepas is. Vgl. SBZ, TdGR: 10.10.1901:495: toespraak van Dürrenmatt. Dié artikel is in 1877 deur die kanton Zürich en in 1882 deur die kanton Neuenburg deur middel van 'n mosie toegepas. In albei gevalle is die versoek aan die Parlement gerig en het dit met militêre belasting te make gehad. 
gelê nie, maar by die vroue en veral die kinders van wie 433 uit elke 1000 gesterf het.

Om die mosie so spoedig moontlik te laat aanneem, was dit nodig om 'n buitengewone sitting van die Grootraad van Bern aan te vra. Op 4 Desember 1901 het die Grootraadspresident, Ed. Will, die lede opgeroep om op 10 Desember te vergader ten einde die Moormosie te bespreek. Dit is gedoen nadat twintig lede van die raad skriftelik daarom gevra het en die president toe uit hoofde van Artikel 1 van die Grootraadsreglement van 20 Mei 1901 en Artikel 32 van die kantonsgrondwet van 1893 verplig was tot so 'n stap.

Voordat die sitting plaasgevind het, is die mosie druk in die pers bespreek. Nie alleen is die persoon van Moor verdag gemaak nie, maar is onder andere ook in die vrysinnige pers beweer dat die mosie bloot bedoel was om probleme vir die Bundesrat te skep en om handel met Brittanje, waarvan Switserland baie afhanklik was, te skaad (Berner Tagwacht: 14.12.1901).

Aangesien die mosie vooraf wye publisiteit geniet het, was daar groot belangstelling vir die buitengewone sitting. Toe Moor eerste aan die woord kom, was die saal en galery van die stadshuis vol belangstellendes, veral uit die geledere van die Parlement. Die een na die ander beswaar soos daaroor in die pers berig is, is deur Moore weerlê. Elke ondersteunende spreker is aan die einde van sy motivering luid toegejuig. Die sprekers het in oortuigende én in emosionele taal gewys op die parallel tussen Switserland en die vegtende Boere ten opsigte van stam, geloof en gewoontes, en op die uitsluitlike doel van die mosie. Met groot oortuiging het die twee parlementslede wat ook lede van die Grootraad was, Von Steiger en die bekende dr. Gobat, hulle stem ten gunste van die mosie laat hoor. Die leier van die Konserwatiewe Party, Dürrenmatt het byvoorbeeld die ellende van die Boerevroue en -kinders vergelyk met Herodes se kindermoord in Betlehem (SBZ, TdGR: 10.10.1901: 495). Ook die bekende bankier Fritz Blösch, Burkhardt en Z'graggen het die mosie sterk gesteun. Hierteenoor het die Nationalrat Bühlmann, Grub, Lenz en Cuénat teen die mosie stelling ingeneem en op regs- en niebeginselgronde gehamer. 24

Ná bykans vier ure se deeglike besinning is die mosie eenparig aanvaar. Die aspekte van menslikheid, groothartigheid en onafhanklikheidsin het dus geseëvier oor kleinlike besware en die 
houding van voetkneg speel vir die regering. Die mosie het ook op 'n ander tasbare wyse tot uitdrukking gekom. Die raadslede het die geld wat hulle vir die dag se sitting ontvang het, aan die inwoners van die konsentrasiekampe geskenk (SBZ, TdGR: 10.10.1901:494).

Op 29 November 1901 is 'n soortgelyke mosie eenparig deur die Grootraad van die kanton Solothurn aangeneem. Die mosie is voorgestel deur 'n sekere Fürholz en gesekondeer deur verteenwoordigers van al die partye in die Kantonsraad (Solothurner Anzeiger: 30.11.1901). Tydens sy motivering van die mosie het Fürholz die oorlog 'n "immoralischer völkerrechtswidriger Krieg - ein Baditenkampf' genoem. 25 So neerhalend was Fürholz in sy toespraak dat die voorsitter hom gemaan het om homself meer diplomaties uit te druk. Daarop het Fürholz sy uitsprake geregverdig deur te stel dat sy aantygings deur alle koerante bewys is (Oltener Tagblatt: 30.11.1901).

Die primêre doel van die mosie was nie 'n materiële nie, maar wel 'n morele oorweging. $\mathrm{Na}$ 'n deeglike en lang bespreking, waartydens die gemoedere soms hoog geloop het en waarvan die toon van die bespreking by dié van Fürholz s'n aangesluit het, is die mosie in 'n ietwat gewysigde vorm aanvaar om soos volg te lees:

Der Kantonsrat beauftragt den Regierungsrat gemäss Artikel 93 der Bundesverfassung, beim Bundesrat zu Handen der Bundesversammlung das Initiativbegehren zu stellen, der Bundesrat sei einzuladen, bei den ausländische Regierungen gemeinsam Schritte anzuregen, um die britische Regierung zu veranlassen, dem öffentlichen, allgemein bekannt gemachten Elend der unglücklichen Burenfrauen und -Kinder in den Konzentrationslagern ein Ende zu bereiten (Soluthorner Anzeiger: 30.11.1901).

Daar was voorstanders en teenstanders van die inhoud van die mosie. Die humanitêre doelstellings van persone wat gemoeid was met die mosies, is deurgaans geloof. Die vraag wat in sowel die Parlement as die pers gestel is, was of die algemene simpatie vir die Boere 'n amptelike stempel moes kry. Die mosies het die Switserse regering dus weer eens binne 'n jaar genoop om standpunt in te neem. Hierdie keer was die probleem meer akuut, aangesien die

Die Duitse woord Bandit beteken rower of vrybuiter. Die rede waarom Fürholz die oorlog as 'n oorlog van rowers beskryf het, was volgens hom omdat die Britte net in die goudmyne en diamantvelde belanggestel het en dit wou inpalm (Oltener Tagblatt: 30.11.1901). 
mosies die regte konstitutionele pad geloop het, voldoen het aan die voorwaarde van die Bundesrat, naamlik om Brittanje nie van onmenslike oorlogvoering te beskuldig nie, en dit 'n saak aangeraak het waaroor nie alleen die Switsers nie, maar ook ander volkere sterk gevoel het.

Die verhouding tussen politiek en reg - reg in die wydste sin as mensereg bedoel - het dus weer ter sprake gekom. Die vraag wat beantwoord moes word, is hoe politieke oorwegings met hul beperkings en gebondenheid aan die konvensies van die volkereverkeer en die daaglikse geykte omgang van die diplomasie kon buig voor en die hand reik aan die beginsels van reg en humaniteit. Met openbare en private gedagtewisseling moes 'n weg gevind word waarop albei aansprake, naamlik dogmatiese en pragmatiese oorwegings, met mekaar versoen kon word.

Die Solothurnse mosie is op 5 Desember 1901 (SBZ, PdB: 1901, inskrywing 4973 (5.12.1901)) en dié van Bern op 12 Desember 1901 (SBZ, PdB, inskrywing 5047 (12.12.1901)) aan die Bundesrat vir optrede oorhandig. Die Bundesrat wou voorbereid wees wanneer die mosies via die Parlement na hulle verwys word. Die Europese, en hierby ingesluit die Switserse pers, het byna daagliks berigte geplaas oor elke faset van die konsentrasiekampe, terwyl Emily Hobhouse gereeld aangehaal is. Om standpunt te kon inneem, was dit egter nodig dat die Bundesrat eerstehandse feitekennis moes verkry. Op 11 Desember het die Politieke Departement telegrafies aan Bourcart laat weet om die Departement so noukeurig moontlik in te lig oor die toestande in die konsentrasiekampe en om die berig wat beweer dat die administrasie van die kampe nie meer in die hande van die militêre personeel is nie, maar deur die Departement Koloniale Sake beheer word, te verduidelik. Drie dae later stuur Bourcart 'n telegrafiese antwoord en volg dit 'n dag later op met 'n lywige brief. Hy antwoord nie slegs breedvoerig op al die vrae en stuur die jongste Blouboek van die Britse regering oor die kampe nie, maar stel hom dit ten doel om sy regering by wyse van talle voorbeelde weereens te waarsku teen die nadeel en visieloosheid van samesprekings met die Britse regering (SAB, Bk: 2001/285, Telegram: Bourcart - Brenner (14.12.1901)). 26

Die brief het 'n groot invloed uitgeoefen op die gedagterigting en optrede van die Bundesrat. Bourcart wys nie net as gewete van die

Asook SAB, BK: 2001/285, Brief: Bourcart - Herr Präsident (15.12.1901). 
regering op die gevolge van 'n onverantwoordelike optrede nie, maar was van mening dat die Blouboek die Raad sou oortuig dat die Britse regering wat die konsentrasiekampe betref, self besig wees om sy huis in orde te kry. Die Bundesrat moes nou 'n uitweg soek, aangesien dit nie meer bereid was om te hou by sy onderneming nie, naamlik om 'n simpatieke oor vir die mosies te hê indien die kwetsende aspekte weggelaat word nie.

Reeds op 12 Desember het die Bundesrat die Parlement in 'n brief daarop gewys dat Artikel 93, waarop die mosies hulle beroep het, die kantons die reg gee om voorstelle te maak, maar dat hierdie reg beperk is binne die raamwerk van die grondwet. Om die dilemma met die Manzoni-Gobat-mosie nie weer te herhaal nie, wys die Bundesrat ook verder daarop dat volgens Artikel 102, subparagraaf 8 van die grondwet die Parlement sy magte aan die Raad oordra om namens hom volkereverhoudings te bepaal en om in buitelandse aangeleenthede op te tree (Von Salis, Vol. I:383; Müller, 1944:9697). Die Bundesrat wou dus met hierdie skrywe die Parlement op sy taak en terrein wys en op die feit dat hy (die Bundesrat) die finale seggenskap ten op sigte van die mosies sou hê.

Met die skrywe van hierdie brief het die Bundesrat nog geen besliste modus operandi ten opsigte van die mosies gehad nie. Die Bundesrat kon dit tewens ook nie gehad het nie, aangesien die twee huise van die parlement nog nie die mosies bespreek het nie en daar gevolglik nog geen opdrag aan die Raad gegee is nie. Bourcart se telegram en die imperiale Blouboek het egter 'n prentjie geskilder wat die kabinet oortuig het dat dit beter sou wees indien die mosies nie verder as die twee huise gevoer word nie. By monde van die president, Brenner, het die Bundesrat op 13 Desember 'n formele verklaring aan die huise uitgereik waarin die grondwetlike bepaling benadruk is en gewys is op die nutteloosheid van die mosies.

Tydens die bespreking van die mosies op 17 Desember 1901 in die Ständerat het Brenner persoonlik die standpunt van die Kabinet gestel, naamlik dat sy kabinet groot waardering het vir die menslike oogmerke van die mosies, dat hulle deeglik bewus is van die lyding van die vroue en kinders en dat hulle dit betreur dat die stryd steeds voortduur. Die somtotaal van hierdie feite was egter nie genoegsaam om die Bundesrat te laat optree nie, want die Raad is grondwetlik verplig om altyd nugter en dus nie op grond van sentiment op te tree nie. Die reg om wel op te tree was die prerogatief van die Bundesrat. Die twee huise het dus nie die magtiging gehad om die reg in eie hande te neem om self met 
buitelandse moondhede te onderhandel en in dié proses die Raad slegs as briefdraer in sy onderhandeling te gebruik nie:

Der Bundesrat ist bereit, die Initiative zur Prüfung zu übernehmen. Er wird keine Entschliessung treffen, die als eine unbefugte Einmischung in fremde Händel ausgelegt werden könnte, und er wird dabei die Pflichten, die uns die Neutralität auferlegt, nicht ausser acht lassen. Unter diesen Vorbehalten nimmt der Bundesrat die Initiative an (Neue Zürcher Zeitung: 17.12.1901).

$\mathrm{Na}$ deeglike bespreking het die Ständerat tog besluit om die mosie na die Bundesrat te verwys vir verdere optrede. Die besluit is ook aan die Nationalrat bekendgemaak. Op 19 Desember sluit hierdie huis hom aan by die Ständerat en op 20 Desember is die mosie sowel as ander mosies wat in hierdie verband moontlik nog gestel kon word, oorgelaat aan die Kabinet (SBZ, PNR: Des. 1901, inskrywing 677). Hierdie huis is ook deur Brenner oor die standpunt van die Bundesrat ingelig.

Die saak is hierna deeglik deur die Politieke Departement ondersoek. Op 30 Desember is die bevinding en aanbeveling wat sterk deur Bourcart se brief beïnvloed is, soos volg verwoord:

Das politische Departement ist nun allerdings der Ansicht, dass der Bundesrat sich hüten sollte, sei es allein, sei es in Verbindung mit andern Regierungen, der Regierung Grossbritanniens wegen der Konzentrationslager in Südafrika ingendwelche Vorstellungen zu machen. Denn es unterliegt kleinem Zweifel, dass England eine solche Einmischung in eine innere Angelegenheit nicht dulden würde (SAB, Bk: 2001/85: Auszug aus dem Protokoll der Sitzung des Schweizerischen Bundesrates (3.1.1902)).

Tydens sy sitting van 3 Desember 1902 is hierdie aanbeveling ' $n$ besluit van die Bundesrat gemaak en is voorlopig van die saak afgestap (SBZ, PdB: Januarie 1902, inskrywing 2). Die besluit en motivering is daarna aan die pers bekend gemaak en die pers is versoek om die volk aan te moedig om voort te gaan met private skenkings van geld, klere en lewensmiddele.

\section{Slot}

Switserland se amptelike standpunte oor die Tweede Vryheidsoorlog in Suid-Afrika bied ' $n$ bruikbare voorbeeld van die botsende denkstrominge in die internasionale regsverkeer teen die einde van 
die 19de eeu. Die drie belangrikste oorwegings wat die Switserse standpunte bepaal het, was die volgende:

- Die bestaande positivistiese siening van Switserland se pragmatiese handhawing van neutraliteit in internasionale konflikte;

- die internasionale wêreld se groeiende bemoeienis met die rol van burgerlikes wat deur oorlog geraak word; en

- die dominante rol wat Brittanje in die internasionale wêreld gespeel het.

Die gevolg van laasgenoemde faktor het dit vir Europese state uiters moeilik gemaak om 'n betekenisvolle rol te speel in die voorkoming van oorloë en die verligting van die lotgevalle van burgerlikes in die geval van oorloë. In die geval van die Switserse standpunt aangaande die oorlog en sy moontlike humanitêre intervensie, het die pragmatiese magspolitieke oorwegings van die tyd dit vir dié land bykans onmoontlik gemaak om aktief by die stryd betrokke te raak. Die gevolg daarvan was dat binnelandse druk onder leiersfigure wat met die burgerlikes in Suid-Afrika gesimpatiseer het, sterk toegeneem het, alhoewel Switserland met moeite sy rol van nie-inmenging in die internasionale regs- en politieke verkeer kon handhaaf. Die skrif was egter reeds aan die muur. 'n Nuut ontwakende sentiment ten gunste van groter humanitêre betrokkenheid in oorloë buite Switserland was merkbaar. Hierdie sentiment was ook tekenenend van die internasionale gemeenskap se groterwordende bekommernis oor die lot van burgerlikes in die geval van oorlog.

Veral twee lesse is uit die Switserse houding teenoor die oorlog in Suid-Afrika te leer:

- Die oorlog het 'n belangrike waterskeiding in die internasionale denke oor die uitgediende positivistiese denkbeelde oor oorlog en die rol van burgerlikes verteenwoordig.

- 'n Gesonde magsbalans in die internasionale arena is 'n belangrike waarborg vir die intervensie van state, ten einde die lyding van oorlog te versag.

\section{Geraadpleegde bronne}

AMERY, L.S. 1900-1909. The Times history of the war in South Africa, 18991902. Vol. I-VI. London: Sampson Law \& Martson. 
ANON. 1950. Gobat, Charles-Albert (In De Bruyne, E., Hiltermann, G.B.J. \& Hoetink, H.R., reds. Winkler Prins Encyclopaedie. Vol. IX. Amsterdam: Elsevier. p. 609.)

BASLER NATIONAL ZEITUNG. Uitgawe 11.12.1900.

BERNER TAGWACHT. Uitgawe 14.12.1901.

BREYTENBACH, J.H. 1969-1977. Die geskiedenis van die Tweede Vryheidsoorlog in Suid-Afrika, 1899-1902. Vol. I-IV. Pretoria: Die Staatsdrukker.

DAS VATERLAND. Nommer 283, 1900.

DAVENPORT, T.R.H. 1986. William Philip Schreiner. (In De Kock, W.J. \& Krüger, D.W., reds. Suid-Afrikaanse biografiese woordeboek. Vol. II. Pretoria: Raad vir Geesteswetenskaplike Navorsing. p. 652-655.)

DE SALIS, J.R., HENDERSON, A. \& HENDERSON, C. 1971. Switzerland and Europe. London: Wolff.

DER BUND Uitgawes 1900/1901. 21-22.12.1900; 26.12.1900; 8.12.1901.

GOOCH, G.P. \& TEMPERLEY, H. 1927. British documents on the origins of the war 1898-1914. London: HMSO.

KRIEL, J.D. 1956. Emily Hobhouse en die nawee van die Anglo-Boereoorlog: 'n studie van altruïsme en pasifisme. Bloemfontein: UOVS. (D. Phil.proefskrif.)

KRÜGER, D.W. 1977. William Johannes Reitz. (In Krüger, D.W. \& Beyers, C.J., reds. Suid-Afrikaanse biografiese woordeboek. Vol. I. Pretoria: Tafelberg. p. 529-533.)

LANGER, W.L. 1972. Encyclopedia of world history. Fifth edition. London: Harrap.

LEPSIUS, J., MENDELSSOHN-BARTHOLDY, A. \& THIMME, F. 1923-1926. Die Grosse Politik der Europaischen Kabinette, 1871-1914; Sammlung der diplomatischen Akten des Auswartigen Amtes. Berlin: Deutsche Verlagsgesellschaft für Politik und Geschichte.

LEYDS, W.J. 1930-1934. Eenige correspondentie uit 1899. Tweede druk (asook Tweede tot Vierde Versameling). Amsterdam: De Bussy.

MÜLLER, H.M. 1944. Über das Verhältnis von Bundesversammlung und Bundesrat in der Führling der auswärtigen Politik. Bern: Recht.

NEUE ZÜRICHER ZEITUNG. Uitgawe 17.12.1901.

OLTENER TAGBLATT. 1901. Uitgawe 30.11.1901.

OTTO, J.C. 1954. Die konsentrasiekampe. Kaapstad: Nasionale Boekhandel.

PIENAAR, A.J. 1975. Christiaan Roedolf de Wet in die Anglo-Boereoorlog. Potchefstroom: PU vir CHO. (M.A.-verhandeling.)

PRETORIUS, F. 1976. Die eerste dryfjag op hoofkommandant C.R. de Wet. Pretoria: Suid-Afrikaanse Akademie vir Wetenskap en Kuns. (Christiaan de Wet-Annale.)

RAATH, A.W.G. \& STRYDOM, H.A. 1999. The Hague Conventions and the Anglo-Boer War. South African Journal for International Law, 24:149-165.

SCHOLTZ, G.D. 1939. Europa en die Tweede Vryheidsoorlog, 1899-1902. Johannesburg: Voortrekkerpers.

SCHOWALTER, A. 1902. Amtliche Berichte sowie andere Urkunden über den Südafrikanischen Krieg. München: Lehmann.

SOLOTHURNER ANZEIGER. Uitgawe 30.11.1901.

SPIES, F.J. DU TOIT. 1946. 'n Nederlander in diens van die Oranje-Vrystaat. Amsterdam: Swets \& Zeitlinger. 
SPIES, F.J. DU TOIT. 1968. Muller, Hendrik Pieter Nicolaas. (In De Kock, W.J., ed. Dictionary of South African bibliography. Vol. III. Bloemfontein: Nasionale Boekhandel. p. 570-571.)

UHL, O. 1961. Die diplomatisch-politischen Beziehung zwischen Grossbritannien und der Schweiz in der Jahrzehnten vor dem Ersten Weltkrieg (1890-1914). Basel: Helbing \& Lichtenhahn.

VON SALIS, L.R. 1903-1904. Schweizerisches Bundesrecht. Bern: s.n.

ZÜRICHER POST. Uitgawe 11.12.1900.

\section{Regeringsverslae}

BRITSE BLOUBOEKE. 1900. Cd. 524: Return of buildings burnt in each month from June 1900 to January 1901 including farm buildings, mills, cottages and hovels.

BRITSE BLOUBOEK. 1901. Cd. 902: Further papers relating to the working of the Refugee Camps in South Africa.

BRITSE WITSKRIF. 1902. Africa No. 1: Correspondence with the Netherland Government regarding the War in South Africa. Presented to both Houses of Parliament by command of His Majesty, February, 1902.

\section{Gepubliseerde argivale bronne}

KANTONALES STAATSARCHIV, BERN. 1901. Tagblatt des grossen Rates. Uitgawes 10.10.1901; 20.11.1901.

\section{Ongepubliseerde argivale bronne}

KANTONALE STAATSARGIEF, BERN (SAB). 1899-1902. Archiv des historischen Vereins des Kantons Bern. Band 519.

KANTONALE STAATSARGIEF, BERN (SAB). 1899, 1900. Lêers 2001/283; 2001/284; 2001/292; 2001/293.

KANTONALE STAATSARGIEF, BERN (SAB). 1902. Africa No. 1. Correspondence with the Netherland Government regarding the War in South Africa. Presented to both Houses of Parliament by command of His Majesty, February 1902.

PUBLIC RECORD OFFICE, LONDON (nou bekend as THE NATIONAL ARCHIVES (TNA)). 1902. Africa no. 2; Lêers F.O.: 192/152, Nr. 22 (4.12.1899); 192/152 (18.12.1899); 2/511, Nr. 50 (30.11.1901); Nr. 52 (5.12.1901); Nr. 56 (11.12.1901); Nr. 57 (14.12.1901); Nr. 58 (18.12.1901); Nr. 59 (20.12.1901); Nr. 61 (30.12.1901); 192/160, Nr. 13 (25.3.1902); 371/339/26738 (8.8.1907); 2/511, Nr. 13 (10.8.1901).

SENTRALE BIBLIOTEEK ZÜRICH (SBZ). Protokoll des Bundesrates (PdB). 1899-1902: 1899: Nrs. 4049 (17.10.1899), 4521 (24.11.1899), 4530 (27.11.1899). 1900: Nrs. 195 (19.1.1900), 1625 (12.4.1900), 2225 (28.5.1900). 1901: Nrs. 3456 (13.8.1901), 3980 (27.9.1901), 4973 (5.12.1901), 5047 (12.12.1901). 1902: Nr. 2 (3.1.1902).

SENTRALE BIBLIOTEEK, ZÜRICH (SBZ). Protokoll Nationalrat (PNR). 1900: Nrs. 32, 367, 380, 651. 1901: Nr. 677.

SENTRALE BIBLIOTEEK, ZÜRICH (SBZ). 1900. Berichte des Bundesrates an die Bundesversammlung seiner Geschäftsführung. 
SENTRALE BIBLIOTEEK, ZÜRICH (SBZ). 1900. Verhandlung der Bundesversammlung.

\section{Kernbegrippe:}

Anglo-Boereoorlog

humanitêre oorwegings

neutraliteit

positivisme

Switserland

\section{Key concepts:}

Anglo-Boer War

humanitarian considerations

neutrality

positivism

Switzerland 